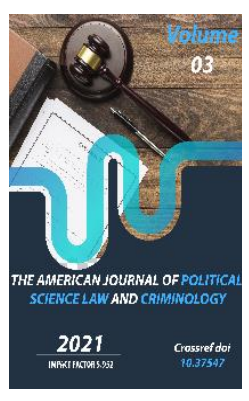

\title{
Strong Emotional Arousal (Effect) As A Criminal Law Norm
}

Copyright: Original content from this work may be used under the terms of the creative commons attributes 4.0 licence.

Niyozova Salomat Saparovna

Doctor Of Law, Acting Professor Of The Department Of Criminal Law, Criminology And AntiCorruption, Tashkent State University Of Law, Uzbekistan

\section{ABSTRACT}

This scientific article will address strong emotional arousal as the norm in criminal law. It also analyzes the views and opinions of scholars in this regard and provides relevant recommendations for improving the theory of criminal law.

\section{KEYWORDS}

Strong emotional arousal, effect, crime, punishment, liability, legal and socially dangerous act, human, physiological effect.

\section{INTRODUCTION}

Indeed, human life is the highest blessing.No one has the right to deprive him of life. Lawyer M. H Rustambaev expresses "the principle of humanity and justice in criminal law in two different ways.In particular, 1) the principle of humanity and justice establishes criminal liability to those who have committed a socially dangerous act that encroaches upon human rights.2) The principle of humanity and justice in the legislation of Uzbekistan includes all 
aggravating and mitigating circumstances against the accused"1 .

"Mitigating circumstances are added as a criterion when the courts take specific measures under criminal law" 2 . In the section on crimes against the personality in the Criminal Code, the violation of a person's life, health, sexual freedom, family interests, youth morals, dignity, constitutional rights and freedoms of citizens is written as socially dangerous acts. Everyone has the right to live, liberty and to own a private property.

The right to exist is the inalienable right of every human being. Attempts on anyone's life shall be regarded as the gravest crime.Thus homicide can be intentional or reckless.Murder-related, all crimes are considered to have resulted in the death of the person, usually homicide is the result of active behavior. Such behavior is manifested in the actions of stabbing the human body, falling him from a height, poisoning, and so on. Deprivation of human life can also occur through inaction. In this case, the failure to take advantage of the opportunity to prevent the death of another person, for example, the neglect of a newborn baby, the death of a patient as a result of failure to carry out the necessary treatment by a doctor.

There must be a causal link between a socially dangerous act and death. The absence of such a causal link means that there is no criminal liability for death. Under current criminal law, the following are included as crimes against a person; Intentional homicide (Article 97 CC), intentional homicide in a state of intense emotional arousal (Article $98 \mathrm{CC}$ ), intentional

\footnotetext{
${ }^{1}$ M.X.Rustamboev. Crimes against the person -

Tashkent. Eldimur. 1998.

${ }^{2}$ V.S.Minskaya. The role of mitigating circumstances in the individualization of criminal liability $\backslash$

Problems of improving criminal legislation and the practice of its application. Sat. scientific papers. - M; 1981 -B. 101-102.
}

homicide of a baby his own mother (Article 98 CC), intentional homicide beyond the bounds of necessary defense, (Article $101 \mathrm{CC}$ ), cases of negligent homicide, (Article 102 of the Criminal Code) to the level of suicide (Article 103 of the Criminal Code). It should be noted that crime rate in the state of effect has increased significantly over the last decade.Intentional homicide, assault, and other crimes are common, especially in the state of effect.

In the sciences of psychology, psychiatry, strong mental arousal is called a physiological affect ${ }^{3}$.

The fact that the crime was committed in a state of physiological affect is the basis for the mitigation of criminal liability, as strong emotional arousal appears in response to the victim's illegal behavior.

During intense emotional arousal, emotional outbursts occur, reducing the stability of mental functions and adversely affecting a person's behavior.

Negative aspects cannot affect well-educated individuals because such individuals can understand the consequences of their behavior even in a state of strong emotional arousal or strong anger, only those who are not well-mannered are able to kill during strong anger.

Criminal behavior is the emotion appearing in the emergence of a character and, moreover, the higher the emotional depression, the more it affects his perception and will.

\footnotetext{
${ }^{3}$ O.D.Sitovskaya. Questions of forensic psychological examination of the state of passion. Questions of forensic psychological examination. M.1996. S. 16-17.
} 
Therefore, how emotions affect the human mind depends on various factors. A person's emotional behavior affects some of his organs. Human behavior is connected not only with the causal link of his personality, but also with biological, psychophysiological conditions.

Human curiosity is emotional and includes followings:

Firstly, sensitivity is an effective state of a person's sensitivity to emotions, movements

Secondly, impulsivity is speed, which is embodied as a force that arouses such emotions and behavior, which has a strong effect on the human mind;

Thirdly, emotional variability is an emergency condition in which a person's emotional state is stopped.

Because of the features mentioned above, curiosity is determined by the stability of the emotional arousal and the speed at which it occurs.

The jealous type commits a crime in certain situations, and such jealousy has an impact on the commission of a crime. This is especially true of a situation of anger.

Taking the individual capabilities into account, they are able to adequately assess the situation.

According to German lawyers, "criminals always falls into a state of choleric affect, excluding the state of sanity"4.

Types of curiosity, other psychophysiological factors determine the shape and

\footnotetext{
${ }^{4}$ Maurach R Zirf H Stalrecht Allgemtiner Teil Teilf and I - Heidelberd 1983 - S.456.

5 Salomat Saparovna Niyozova. Legal Conditions

For The Lawfulness Of Necessary Defense. The

USA Journals Volume 03 Issue 01-2021. - P.28.
}

characteristics of a person with the onset of emotion.

In the study of highly emotional offenders, the difference in crime between women and men is more significant. This is because when comparing the characteristics of women's crime with crimes committed by men, it was found that there is a significant difference in the psychological characteristics of women in this regard.

Persons, who are attacked, in most cases, are in a state of fright, in a state of strong emotional excitement, that is, passion. That is why the person is not able to fully assess the current situation. In addition, you cannot demand from him to correctly measure the nature and danger of an attack. It proceeds from this that it is always necessary to take into account the mental state of the person, which was caused precisely by the encroachment ${ }^{5}$.

The motive for women's crime is tension, aggression, impulsivity. In addition, a stable and definite period of mental process was found to increase in women. That is why the commission of a crime by a pregnant woman is included in the criminal law as a mitigating circumstance $^{6}$.

It is also "recognized as a mitigating circumstance, given the particular psychophysiological condition of the mother, whether intentionally killing her infant, directly during birth or after birth"”.

The emotional sphere of a person changes during the process of growth and development, which is a legitimate process and is a condition for the physical and mental development of a person. An increase or

\footnotetext{
${ }^{6}$ M.N.Golodnyuk "Problems of social and biological in female crime" $\backslash$ Questions of combating crime Issue 37.,1982.-P.23.

7 M.X.Rustamboev. A crime against the person. T.1998. Eldimur. - P.51.
} 
decrease in the impulse is observed at different times of the growth period.

Naturally, the occurrence of an affective emotional state varies. The focus is on juvenile delinquency. (11-12-15 years old) adolescent's character is formed and during this period injustice or insult can be deeply broken by them.

M.H.Rustambaev states that "it is difficult to control the actions of a minor under the age of 16 when he has an effective state" 8 .

The emergence of a strong emotional state in the effect leads to a deterioration of human health, the development of a serious illness. It creates anger towards healthy people. It is important to note the impact of alcoholism on the human emotional sphere.

"Alcohol affects the central nervous system, arouses negative emotions in a person and enhances the qualities of revenge, anger, violence".

All of the above factors do not in themselves reduce a person's emotional potential and lead to unlawful behavior.

"In practice, it has been observed that there are cases of physical violence that cause strong emotional excitement"'.

Most crimes stem from mutual quarrels between relatives. Until recently, effect was viewed in the legal literature as an element of crime and has been studied in determining the subjective aspect of the crime. However, such an approach meets the level of development of modern legal science, as well as the requirements of practical jurisprudence. Legal science implies an emotional attachment as a condition that determines the nature of an

\footnotetext{
${ }^{8}$ M.X.Rustamboev. Responsibility for a crime against health under the legislation of the Republic of Uzbekistan. Nukus. 1992, - P. 71-72.
}

unlawful behavior. Strong mental arousal does not change the content of the crime, but rather explains the circumstances in which the crime was committed.

The peculiarity of crimes committed in the state of effect is that not only the victim but also the accused need legal protection in committing a crime.

The distinguishing feature of effective crimes is that the person who commits the crime is in a state of particular emotional distress and is unable to control his or her behavior.

The main reason for the strong mental arousal of the perpetrator is the victim's illegal action. That is why the legislature recognizes the sudden onset of emotional arousal as a mitigating circumstance. At the same time the sanction of certain articles of the Special Part of the Criminal Code for liability for certain crimes in the above case is significantly lower.

An affect is a state of mind that is very strong, appears quickly, and is strong, lasting for a short time. What happens when a person is in a state of affect is like an "explosion".

Affect is as different as a person's mental state. There are many types of effects such as anger, rage, fear, grief, joy, and so on. The existence of this or that species depends on the situation that led it to it.

Physiological effect is short-lived but intense emotional arousal, overt, short-lived seizures, and at the same time, extremely intense, intense experiences, anger that turns into intense anger, fear that turns into panic, grief at the level of despair, resulting in guilt loses the ability to control their own movements and

\footnotetext{
${ }^{9}$ Experimental psychology $\backslash$ red Sost P Fress, J.Piage Vip 5,- M.1975.
} 
the ability to control them in the short term ${ }^{10}$.

In turn, S.Eloyan says that "when a crime is committed in an emotional state, the commission of the crime is a surprise for the guilty person, his relatives and acquaintances, and is incompatible with the usual behavior of the guilty person. Effect can develop in anyone, but not all people allow it to develop"11.

In this regard, according to NS Volkov, in assessing whether a state of effect has arisen, the actions of the victim do not have to be defined as a crime, such actions can be any attempt to discriminate, insult, otherwise provoke anger of the person ${ }^{12}$.

In a state of physiological effect, it is difficult for the offender to control and direct his or her actions. However, as he is able to control and manage his actions, he will be the basis for criminal prosecution. In turn, it is required to prove that the person has committed a crime in a state of effect.If we look at the case law of foreign countries, the Criminal Court of the Supreme Court of the Russian Federation considered the criminal case of Shilov's murder of his wife and concluded that Shilov was in a state of physiological effect at the time of the crime. During all the interrogations, Shilov did not remember how he hit his wife, where he got the knife, where the children were at the time, whether they shouted or not, and the police officer immediately told the police that Shilov had killed his wife, that is, Shilov immediately reported to the police station that he had killed his wife, citing his testimony that he was barefoot at the time and told what had happened in a state of tremor ${ }^{13}$.

10 M.X.Rustamboev. Course of criminal law of the Republic of Uzbekistan. Volume 3. Special Section. Crimes against the person. Crimes against peace and security. Textbook. 2 edition, supplemented and revised. - T.: Military Technical Institute of the National Guard of the Republic of Uzbekistan, 2018. -Page 76; M.X.Rustamboev Comments on the Criminal Code of the Republic of Uzbekistan. (Special section). - T.:ILM ZIYO, 2006. - B. 41.
In turn, in order to find a person guilty of a crime in a state of intense emotional arousal, in addition to proving that he was in such a state at the time of the crime, it is necessary to prove that the person's emotional state arose suddenly as a response to the victim's illegal actions. This requires that the time between the victim's illegal behavior and the onset of an affective state be kept to a minimum.

In turn, MI Kovalev believes that "strong emotional arousal should be caused by sudden, illegal actions of the victim (violence, discrimination, insults) established by law, and remembering these actions when meeting the victim does not cause effect. Judicial practice should be based on this decision ${ }^{14}$.

In turn, the effective state may result from discrimination or severe insult committed by the victim. It can be expressed in a sense of patriotism, in laughter over physical defects.

Crimes committed in a state of intense emotional excitement spread over a long period of time. An example of this, we can take the ancient Roman law. It is also known from the practice of Russian jurisprudence that according to Article 18 of the Russian Act, a person is given a lenient sentence for committing a crime of insult.

The concept of strong mental arousal itself was different in jurisprudence. For example, "Russian criminal law in its time, under the influence of psychophysiological, psychological advances, has given up the terms primarily curiosity and anger. For example,

11 Eloyan S.A. Problems of qualification of crimes committed in a state of passion // Successes of modern natural science. -№8, 2011. - S.254-155.

${ }^{12}$ Volkov N.S. Affect, its meaning. - M. 2010. - P.65.

13 Bulletin of the Supreme Court of the Russion Federation. 2008. -№1. - P.8-9.

${ }^{14}$ Kovalev M.I. The degree of public danger // State and law. - 1995. - №9. 
Section 48 (2) of the 1903 Penal Code provides for liability for aggravated assault by a victim or use of force against a person for the purpose of killing a person as a result of strong emotional arousal”'

Since then, the concept of strong emotional arousal has been firmly entrenched in criminal law theory and is used in criminal law.

It is necessary to propagate among the population the provisions of necessary defense in the legislation of the Republic of Uzbekistan. Raising public awareness is an important aspect. Citizens should not have fear of unjustified criminal prosecution ${ }^{16}$.

\section{CONCLUSION}

Based on the above, the following conclusions can be drawn:

1) A strong emotional excitement can put a person in a state of sudden effect, regardless of whether the betrayal of a partner is suddenly known or has long been suspected of that;

2) To pay attention to the need to conduct a forensic psychiatric examination of each criminal case in order to determine the status of effect in order to avoid possible errors in the classification of the act committed by the courts under Article 98 of the Criminal Code;

3) Intentional homicide committed in a state of sudden strong emotional arousal due to infidelity may be qualified by Article 98 of the CC.

Because, firstly, the infidelity that gave rise to the crime is of a demonstrative nature,

\footnotetext{
${ }^{15}$ Code of punishment 1845-1855 (Article 1455,Part 2) Russion True. - Regulations on Punishments 1845-1855, in particular, to alleviate liability for murder for jealousy. This sentence is similar to the term in Russion reality.

${ }^{16}$ Salomat Saparovna Niyozova. Legal Conditions For The Lawfulness Of Necessary Defense. The USA Journals Volume 03 Issue 01-2021. - P.28.
}

committed in order to irritate the sexual partner, to insult his honor and dignity, to damage his reputation, in such cases infidelity is a serious insult and the act is punishable under the Criminal Code. There will be sufficient grounds to conclude that it was committed in a state of intense emotional excitement as provided for in Articles 98 and 108.

Secondly, the recurrence of infidelity is a sign of immorality, and it leads to a situation that hurts the nerves. It is possible to impose a lighter sentence for the crime of premeditated murder, committed in a state of mental excitement under the influence of such a situation. In all other cases, sexual intercourse with a third party, the transfer of emotions to other persons, is considered a moral violation, taking into account the current rules of sexual intercourse, the crime committed in response to such behavior is a case of strong emotional arousal under Article 98 of the Criminal Code. It would not be correct to qualify it as an act committed .

On the basis of the implemented reforms and the agreements reached between the parties, various barriers existing at the state borders with neighboring countries have been eliminated. As a result, from 2017 to 2018, there was a sharp decline in crime in this area ${ }^{17}$.

\section{REFERENCES}

1. M.X.Rustamboev. Crimes against the person - Tashkent. Eldimur. 1998.

2. V.S.Minskaya. The role of mitigating circumstances in the individualization of criminal liability \Problems of improving criminal legislation and the practice of its

\footnotetext{
17 Алланова А.А. Қонунга хилоф равишда чет элга чиқиш ёки ўзбекистон республикасига кириш учун жиноий жавовгарлик: муаммо ва таклиф //юрист ахборотномаси. - 2021. - Т. 2. - №. 1. - С. 166-174.
} 
application. Sat. scientific papers. - M; 1981-B. 101-102.

3. O.D.Sitovskaya. Questions of forensic psychological examination of the state of passion. Questions of forensic psychological examination. - M.1996. S. 16-17.

4. M.N.Golodnyuk "Problems of social and biological in female crime" | Questions of combating crime Issue 37.,1982.-P.23.

5. M.X.Rustamboev. A crime against the person. - T.1998. Eldimur. - P.51.

6. M.X.Rustamboev. Responsibility for a crime against health under the legislation of the Republic of Uzbekistan. Nukus. 1992, - P. 71-72.

7. Kovalev M.I. The degree of public danger // State and law. - 1995. - №9.

8. V.V.Orekhov Necessary defense and other circumstances precluding the criminality of the act.- St. Petersburg: "Piter ubl", 2008. - P.46.

9. Kozak V.N. The Right of Citizens to Necessary Defense. - Saratov: "Publishing house Sarat", 1972. - P.41..

10. S.V.Borodin Responsibility for murder: qualification and punishment under Russian law. - M: Jurist, 1994. - P. 93.

11. Алланова А. қонунга хилоф равишда чет элга чиқиш ёки ўзбекистон республикасига кириш учун жиноий жавовгарлик: муаммо ва таклиф//юрист ахборотномаси. - 2021. - Т. 2. - №. 1. - С. 166-174.

12. S.S.Niyozova. Legal Conditions For The Lawfulness Of Necessary Defense. The USA Journals Volume 03 Issue 01-2021. P.28. 